\title{
Zinc Bioremoval from Wastewater of Rubber Glove Industry
}

\author{
Azizah Abu-Bakar \\ Department of Chemical and Process Engineering, Faculty of Engineering \\ Universiti Kebangsaan Malaysia (UKM), 43650 Bangi, Malaysia \\ Tel: +603-89216428Ｅ-mail: aziey_ab@yahoo.com \\ Rakmi Abd-Rahman \\ Department of Chemical and Process Engineering, Faculty of Engineering \\ Universiti Kebangsaan Malaysia (UKM), 43650 Bangi, Malaysia \\ E-mail: rakmi@vlsi.eng.ukm.my \\ Abu Bakar Mohamad \\ Department of Chemical and Process Engineering, Faculty of Engineering \\ Universiti Kebangsaan Malaysia (UKM), 43650 Bangi, Malaysia \\ E-mail: drab@vlsi.eng.ukm.my \\ Abdul Amir Hassan Kadhum \\ Department of Chemical and Process Engineering, Faculty of Engineering \\ Universiti Kebangsaan Malaysia (UKM), 43650 Bangi, Malaysia \\ E-mail: amir@vlsi.eng.ukm.my \\ Siti Rozaimah Sheikh Abdullah \\ Department of Chemical and Process Engineering, Faculty of Engineering \\ Universiti Kebangsaan Malaysia (UKM), 43650 Bangi, Malaysia \\ E-mail: rozaimah@vlsi.eng.ukm.my
}

The research is financed by Asian Regional Research Programme on Environmental Technology (ARRPET II) and Ministry of Science, Technology and Environment, Malaysia (IRPA 08-02-02-0003 EA094 Grant).

\begin{abstract}
Conventional physicochemical processes for removing heavy metals from industrial effluents are high in chemical usage and produce large amounts of chemical sludges, which in turn needs secured disposal. Biological processes to overcome these problems have been developed for treating wastewaters containing heavy metals. The bioremoval and biorecovery of zinc ions from rubber glove mill effluent on a sequencing batch biofilm reactor (SBBR) was studied. Without adding any precipitant, the processes could achieve Zn and COD removal of $40-60 \%$ and $50-70 \%$ respectively. In order to recover the metal, the sludge was digested in an anaerobic digestion reactor. This study revealed that anaerobic digestion with longer hydraulic retention time could increase the recovery of heavy metals. This recovery prevents metal discharge to the environment and conserves resources.
\end{abstract}

Keywords: Biofilm, Anaerobic digestion, SBBR

\section{Introduction}

Increasing awareness of accumulation of heavy metals in the environment has led to a quest for new and improved "clean" technologies. The contamination of the environment by heavy metals is of growing concern because of the numerous health risks to animals and humans following exposure (Costley and Wallis 2001). Common sources of metal polluted wastewaters include electroplating plants and other, metal finishing operations, as well as many mining, nuclear and electronics industries. All of these contribute to anomalously high concentrations of metals in the environments relative to the normal background levels (Neytzell-De Wildes 1991).

Wastewater treatment plants are expected to control the discharge of heavy metals to the environment. However, with new stricter regulations aimed at protecting the environment, wastewater treatment authorities are facing with disposal 
problems of heavy metal laden sludge (Chipasa 2003). Toxicity of heavy metals is well documented (Nies 1999). The problems associated with heavy metals in the environment are their accumulation in the food chain and their persistence in nature. Heavy metal ions are accumulated by microorganisms, and a number of investigators have shown that microorganisms are valuable tools in removing and recovering metals from waste streams.

Microbial metal accumulation has received much attention during recent years, due to the potential use of microorganisms for treatment at metal polluted water or wastewater streams (Zouboulis et al. 2004). Biological processes have shown potential for heavy metal removal (Volesky 1987; Bux et al. 1994). In a biofilm processes, dissolved organic materials and nutrients are directly absorbed from bulk phase to the biofilm by means of concentration gradient, whereas dissolved heavy metals are generally adsorbed onto the biofilm surface as a result of interactions between metal ions and the negatively charged microbial surfaces, gradually reducing the aqueous metal concentration (Jang et al. 2001). Hence, this research aims to investigate the efficiency of metal removal and recovery in rubber glove mill wastewater via a biosorption process.

\section{Method and Material}

\subsection{Bioremoval and biorecovery process}

A laboratory scale sequencing batch biofilm reactor (SBBR) was set up as shown in Figure 1. The reactor of volume $1 \mathrm{~L}$ was operated at hydraulic retention time (HRT) of one day. At start up, it was seeded with a mixed culture acclimatized to simple and complex organics. Real industrial wastewater from a rubber glove mill was taken as the influent for the reactor. After sampling, samples were taken to the laboratory and immediately analyzed.

After being treated in the SBBR for a period of time, the resultant sludge with the biomass was separated from the effluent. The sludge was digested in an anaerobic digestion reactor of $500 \mathrm{~mL}$ for metal recovery. HRTs of 5 and 10 days were used for the digestion process to compare the metal recovery. Metal contents in the sludge after and before anaerobic digestion treatment was analyzed using AAS through acid digestion method. Additionally, a water displacement system was used to collect the gas which was produced as a result of the anaerobic digestion process.

\subsection{Sample Analysis}

Effluent samples from the SBBR were filtered through a $0.45 \mu \mathrm{m}$ pore membrane filter (Whatman) and the filtrate was analyzed for COD and heavy metals. The metal contents were analyzed using Atomic Absorption Spectroscopy (AAS). COD was spectrophotometrically analysed using HACH DR2000 Spectrophotometer. Analysis of methane in the collected gas was achieved by a gas chromatography equipped with a flame ionization detector (FID). Table 1 summarizes the method and the instrument used in sample analysis and Table 2 lists the operating parameters for the gas chromatography.

\section{Results and Discussion}

The results of sample analysis of the raw rubber mill wastewater are shown in Table 3. The wastewater contained high concentrations of organic matter, suspended solids and zinc which exceeded the standard limits set by Malaysian government.

The removal rate of zinc metal is recorded and presented in figure 2. The zinc content in the effluent were below its standard limit of $1 \mathrm{mg} / \mathrm{L}$. The removal range for zinc is about 40-60\%. According to Oliver and Cosgrove (1974), metal removal occurs in a biological reactor through biosorption process. This bioremoval of zinc does not require chemical addition and result in biological sludge whose volume and weight can be further reduced. Furthermore, a good COD removal in the range of about 50-70\% was also achieved in the system (Figure 3).

The zinc content in the sludge before and after the digestion process is presented in figure 4. It was observed that anaerobic digestion process caused an increase in the content of heavy metals. Longer HRT of 10 days gave a better recovery of the metal compared to a shorter HRT of 5 days. It showed that longer time was required for an effective digestion process to occur in the system. The increases in metal contents in the digested sludge was expected because during anaerobic digestion, biodegradable organic and inorganic matter are de-composed to end products of $\mathrm{CH}_{4}, \mathrm{CO}_{2}$, $\mathrm{N}_{2}, \mathrm{H}_{2} \mathrm{~S}$ and many other gases as reported by Tchobanouglous et al. (2004).

Gas production from anaerobic digestion process was recorded daily using water displacement system. Identification and quantitative analysis of methane in the collected gas were performed using gas chromatography and a result of this analysis was shown in Figure 5. The chromatogram of methane gas found at a retention time of $1.52 \mathrm{~min}$ in compare to authenticated methane sample proved that methane gas was produced in this anaerobic digestion reactor.

\section{Conclusions}

This study has shown that the biofilm process applied can be used to substantially remove both organics and heavy metal from wastewaters and has the potential to be further developed into a cheaper, environmentally friendly process for treating wastewaters containing organics and heavy metals. This technology, which is based on nucleated 
precipitation of heavy metals onto biomass surface in a sequencing batch bioreactor, is viable for removing heavy metals from industrial wastewater.

\section{References}

Bux, F., Swalaha, F. M. \& Kasan, H. C. (1994). Microbiological transformation of metal contaminated effluents. Water Research Commission Report No 357/1/94.

Chipasa, K. B. (2003). Accumulation and fate of selected heavy metals in a biological wastewater treatment system. Waste Management. 23: 135-143.

Costley, S. C. \& Wallis, F. M. (2001). Bioremediation of heavy metals in a synthetic wastewater using a rotating biological contactor. Water Research. 35: 3715-3723.

Jang A., Kim S. M., Kim, S. Y., Lee, S. G. \& Kim, I. S. (2001). Effect of heavy metals (Cu, Pb and $\mathrm{Ni}$ ) on the compositions of EPS in biofilms. Water Science Technology. 43: 41-48.

Neytzell-De Wildes, F. G. (1991). Reassessment of the strategy with respect to industrial effluent discharge with special reference to advanced technology treatment methods: Phase I. Industrial effluent discharge problem areas. Water Research Commission Report No. 407/1/92.

Nies, D. H. (1999). Microbial heavy metal resistance. Applied Microbiology and Biotechnology. 51: 730-750.

Oliver, B. G. \& Cosgrove, E. G. (1974). The efficiency of heavy metal removal by a conventional activated sludge treatment plant. Water Research. 8: 869-874.

Tchobanoglous, G., Burton, F. L. \& Stensel, H. D. (2004). Wastewater Engineering: Treatment and Reuse (fourth edition). New York: McGraw-Hill.

Volesky, B. (1987). Biosorbents for metal recovery. Trends in Biotechnology. 5: 96-101.

Zouboulis, A. I., Loukidou, M. X. \& Matis, K. A. (2004). Biosorption of toxic metals from aqueous solutions by bacteria strains isolated from metal-polluted soils. Process Biochemistry. 39: 909-916.

Table 1. Details of analysis parameters and instruments used

\begin{tabular}{|l|c|c|}
\hline \multicolumn{1}{|c|}{ Parameter } & Method & Instruments \\
\hline COD & $\begin{array}{c}\text { Digestion Method (EPA } \\
\text { approved) }\end{array}$ & HACH DR2000 \\
\hline Metal contents & $\begin{array}{c}\text { Flame Atomic Absorption } \\
\text { Spectrometry }\end{array}$ & $\begin{array}{c}\text { Atomic } \\
\text { (5100PC, Perkin Elmer, U.S.A) }\end{array}$ \\
\hline
\end{tabular}

Table 2. Gas chromatographic parameter for methane gas determination

\begin{tabular}{|l|l|}
\hline Parameter & Analytical conditions \\
\hline GC Model & Hewlett Packard (HP 5890) \\
\hline Detector & FID (Flame Ionization Detector) \\
\hline Column & HP Innowax, L=30 m, ID $=0.25 \mathrm{~mm}$, Film thickness $=0.25 \mu \mathrm{m}$ \\
\hline Carrier Gas & Helium \\
\hline Retention time, $\mathrm{R}_{\mathrm{t}}$ & $1.52 \mathrm{~min}$ \\
\hline Detector temp. & $220^{\circ} \mathrm{C}$ \\
\hline Injector temp. & $160^{\circ} \mathrm{C}$ \\
\hline Program & $60^{\circ} \mathrm{C}$ hold for $1 \mathrm{~min}, 5^{\circ} \mathrm{C} / \mathrm{min}$ up to $130^{\circ} \mathrm{C}$ \\
\hline
\end{tabular}


Table 3. Characteristics of wastewater from rubber glove mill

\begin{tabular}{|l|c|c|}
\hline Parameter & Unit & Value \\
\hline $\mathrm{pH}$ & - & 8.33 \\
\hline COD & $\mathrm{mg} / \mathrm{L}$ & 4320 \\
\hline Suspended solid & $\mathrm{mg} / \mathrm{L}$ & 515 \\
\hline Color & $\mathrm{PtCo}$ & 7380 \\
\hline Copper & $\mathrm{mg} / \mathrm{L}$ & 0.002 \\
\hline Zinc & $\mathrm{mg} / \mathrm{L}$ & $1.169 *$ \\
\hline Nickel & $\mathrm{mg} / \mathrm{L}$ & 0.009 \\
\hline Sodium & $\mathrm{mg} / \mathrm{L}$ & 16.410 \\
\hline Potassium & $\mathrm{mg} / \mathrm{L}$ & 0.852 \\
\hline Calcium & $\mathrm{mg} / \mathrm{L}$ & 0.734 \\
\hline
\end{tabular}

*Standard limit of Zn (Malaysian Environmental Quality Act 1979) = $1.0 \mathrm{mg} / \mathrm{L}$

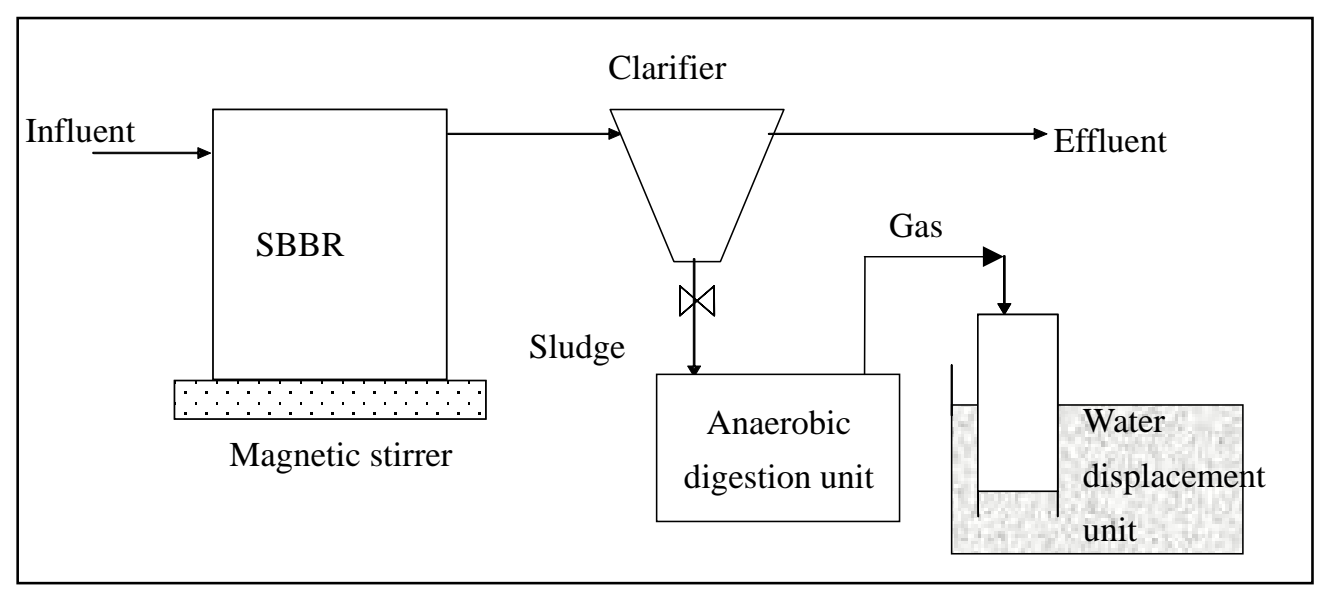

Figure 1. Schematic diagram of bioremoval and biorecovery process

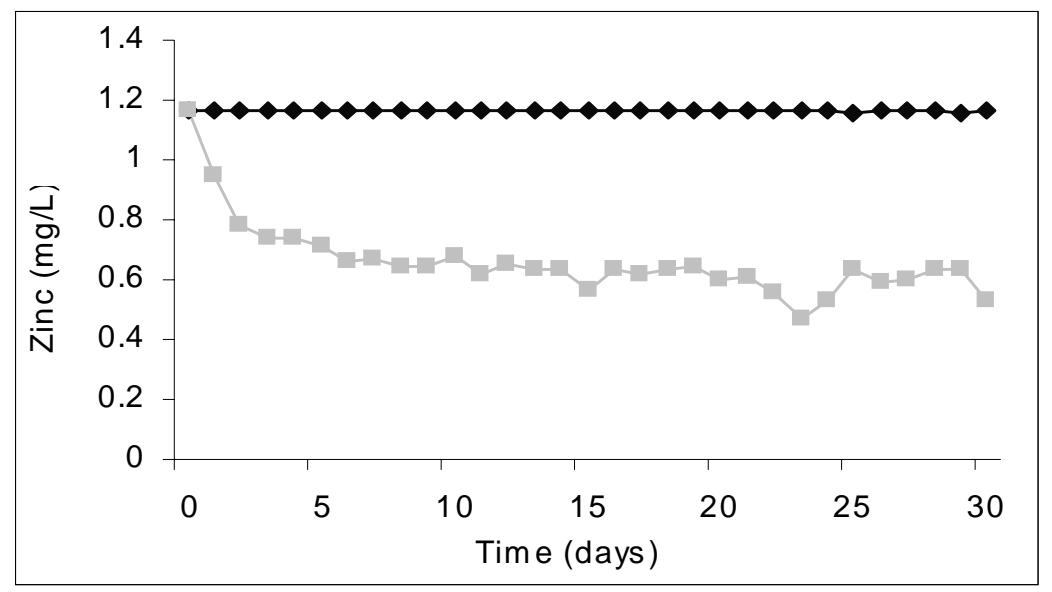

Figure 2. Zinc content in the influent and effluent of SBBR 


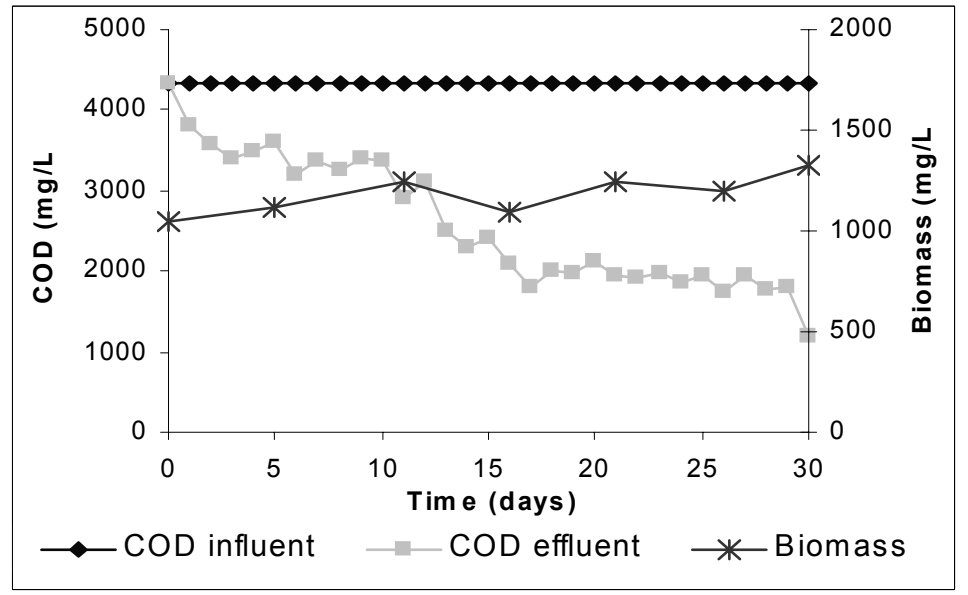

Figure 3. Biomass concentration and COD in the influent and effluent of SBBR

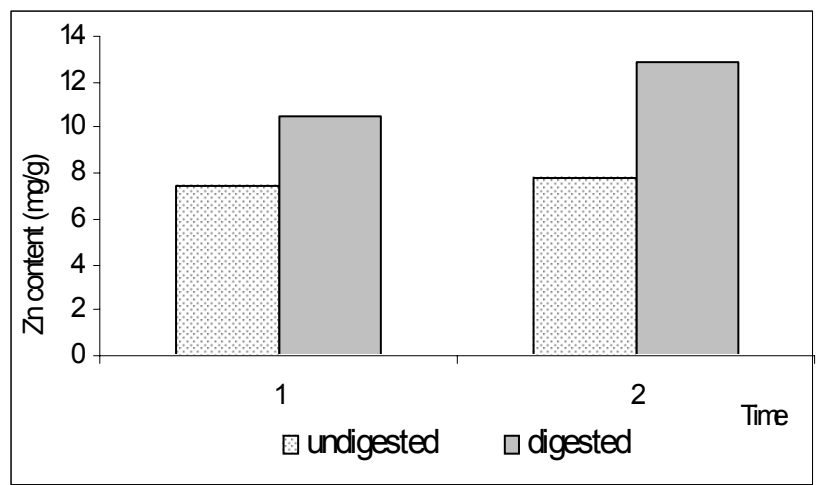

Figure 4. Zinc content after the anaerobic digestion process of different HRTs

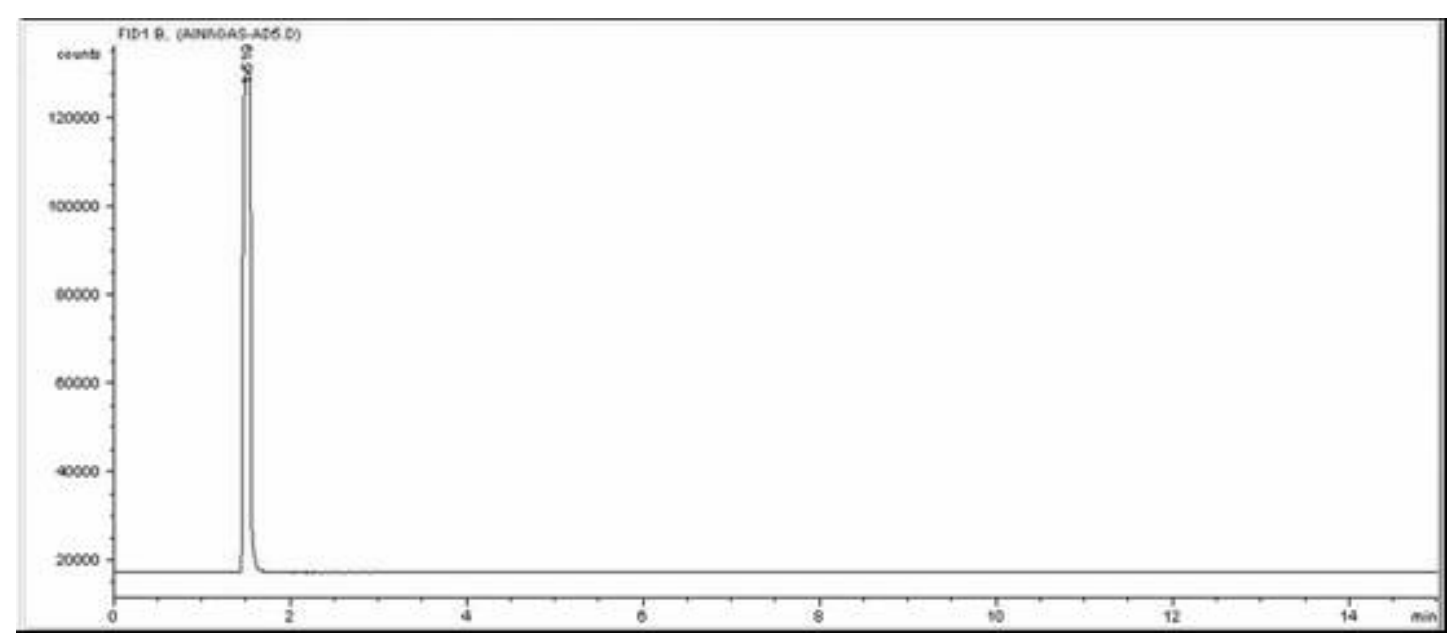

Figure 5. Chromatogram of methane gas 